\title{
Landfast sea ice-benthic coupling during spring and potential impacts of system changes on food web dynamics in Eclipse Sound, Canadian Arctic
}

\author{
Doreen Kohlbach ${ }^{1, *}$, Steven H. Ferguson ${ }^{1}$, Thomas A. Brown ${ }^{2}$, Christine Michel ${ }^{1}$ \\ ${ }^{1}$ Fisheries and Oceans Canada, Freshwater Institute, 501 University Crescent, Winnipeg, \\ Manitoba R3T 2N6, Canada \\ ${ }^{2}$ Scottish Association for Marine Science, Scottish Marine Institute, Oban, Argyll PA37 1QA, UK
}

\begin{abstract}
We investigated the role of sea ice-derived carbon in the food web of Eclipse Sound, Canadian Arctic during the spring ice-covered season to understand the potential ecological impact of changes to the sea-ice habitat. Chlorophyll a (chl a) concentrations in the bottom of sea ice $\left(438.2 \pm 154.2 \mathrm{\mu g} \mathrm{l}^{-1}, 19.8 \pm 6.6 \mathrm{mg} \mathrm{m}^{-2}\right)$ were more than 2 orders of magnitude higher than in surface waters $\left(0.9 \pm 0.7 \mu \mathrm{g} \mathrm{l}^{-1}\right)$. Fatty acid (FA) composition showed that algal communities in the bottom sea ice comprised higher abundances of diatoms compared to surface waters. Benthic invertebrates (ophiuroids, polychaetes) and sediments had high proportions of diatom-associated FAs in their lipid composition. H-Print estimates of the proportional contributions of sea icederived carbon to the carbon pool of the benthic community were substantial, ranging on average between 77 and $85 \%$. High carbon stable isotope values $\left(\delta^{13} \mathrm{C}\right)$ in benthic invertebrates and sediments $\left(\delta^{13} \mathrm{C}\right.$ : -19.6 to $\left.-11.6 \%\right)$ further suggests that a large portion of the benthic carbon pool was of sea-ice origin, while surface waters were significantly lower $\left(\delta^{13} \mathrm{C}:-22.32 \pm 2.17 \%\right)$. In this ecosystem where landfast ice is present for most of the year, strong sea ice-benthic coupling emphasizes the dependency of the food web on ice productivity. As timing and magnitude of sea icederived carbon will change under alterations of climatic conditions and possibly with increased shipping activities in the study region, the adaptive capacity of sea ice-dependent species is anticipated to play a key role in determining future food webs.
\end{abstract}

KEY WORDS: Sea ice · Ice algae · Carbon sources · Climate change · Fatty acids · Stable isotopes · Canadian Arctic $\cdot$ Eclipse Sound $\cdot$ Pond Inlet

\section{INTRODUCTION}

The waters of Eclipse Sound in the Canadian Arctic are part of a frequently used shipping route for iron ore that is in close proximity to Pond Inlet, a predominantly Inuit community located at the northeast tip of Baffin Island (Northern Shipping Route). Relative to other marine areas in the Canadian High Arctic, most of the sea ice in Eclipse Sound is annual landfast ice (Sinha \& Zhan 1996, Shokr \& Sinha 2015), which typically extends over coastal shelves favoring a tight sea ice-benthic coupling (Fortier et

${ }^{*}$ Corresponding author: doreen.kohlbach@awi.de al. 2002, Mahoney et al. 2007, Renaud et al. 2007). Eclipse Sound represents a biologically productive habitat for top predators (Smith 1980) and provides an important water body for intense mammal migration during summer (Richard et al. 1994, Kenyon et al. 2018).

Knowledge of the link between primary producers (algae) and consumers, and its regulating factors is vital to predict energy transfer efficiencies within the food web (Müller-Navarra et al. 2000, Michel et al. 2002). Sea-ice algae can provide an important carbon source for species that inhabit the sea ice itself (in-ice

(C) Fisheries and Oceans Canada and T. A. Brown 2019. Open Access under Creative Commons by Attribution Licence. Use, distribution and reproduction are unrestricted. Authors and original publication must be credited.

Publisher: Inter-Research · www.int-res.com 
fauna) or that dwell in the sea ice-water interface, and even more pelagic species (Michel et al. 2002, Bluhm et al. 2010, Kohlbach et al. 2016). Moreover, benthos can thrive on sea ice-derived carbon, particularly early in the season (McMahon et al. 2006, Renaud et al. 2007, Sejr et al. 2007). In spring, icealgal abundances may increase by several orders of magnitude, providing a sufficient carbon pool to fuel the food web when phytoplankton concentrations are still low (Michel et al. 1996, Mundy et al. 2005, Brown et al. 2011).

Sea-ice extent and thickness are declining in the Arctic Ocean (Pizzolato et al. 2014, Harada 2016) and in the Canadian Arctic (Environment and Climate Change Canada 2016, Stroeve \& Notz 2018), causing alterations in timing, magnitude and spatial distribution of primary production in the sea ice and the water column (Ardyna et al. 2014, Assmy et al. 2017, Blais et al. 2017). This yields profound implications for the dependent ice-associated, pelagic and benthic food webs in the Canadian Arctic (Hobson et al. 2002, Roy et al. 2015, Mäkelä et al. 2017) and other Arctic near-shelf locations (McMahon et al. 2006, Søreide et al. 2013) as well oceanic regions (Kohlbach et al. 2016, 2017). Changes at the base of the food web will affect the energy flow from lower to higher trophic levels with uncertain consequences for top predators (Hays et al. 2005, Wassmann et al. 2011, Wassmann 2015). As climate change is expected to accelerate in the future, it is crucial to improve our understanding of sea ice-related ecosystem dynamics and functioning in their response to environmental changes in the Arctic (e.g. Hollowed et al. 2018).

Reductions in sea-ice coverage enable interoceanic shortcuts for ships through the Arctic, and longer open-water seasons also facilitate longer shipping periods (e.g. Smith \& Stephenson 2013, Pizzolato et al. 2016, Ng et al. 2018). Overall in the Arctic, and in the Canadian Arctic, increased resource development and access can impact the traditional lifestyle of northerners and indigenous people. In Eclipse Sound, potentially extending shipping during the sea-ice covered period (Baffinland Iron Mines Corporation 2016) could negatively impact traditional usage of the sea ice by Inuits for hunting and travel. Moreover, increased shipping might potentially amplify the vulnerability of Arctic organisms to environmental alterations associated with warming (Hauser et al. 2018, Yurkowski et al. 2019). Therefore, it is essential to fully understand the role of sea ice in trophic marine food webs in order to assess potential impacts of shipping during the winter season.
Lipid and stable isotope biomarkers provide invaluable insights into the food web dynamics of complex ecosystems (e.g. Budge et al. 2008, Kohlbach et al. 2016). Fatty acids (FAs) specific to certain algae groups, such as 16:1n-7, 16:4n-1 and 20:5n-3 for diatoms and 22:6n-3 for dinoflagellates (Dalsgaard et al. 2003), can help determine the origin of carbon in a consumer's diet (Budge et al. 2008, Wang et al. 2015) or identify carbon sources in benthic environments (Graeve et al. 1997, Budge et al. 2007), as they are transferred largely unmodified from one trophic level to another (Müller-Navarra et al. 2000, Falk-Petersen et al. 2009). Furthermore, long-chain FAs 20:1 and 22:1 biosynthesized by calanoid copepods (Sargent \& Whittle 1981) can give information on the degree of carnivory of a consumer. Another lipid-based biomarker approach for the characterization of food web interactions uses highly branched isoprenoids (HBIs) (Volkman et al. 1994). A well-characterized HBI is $\mathrm{IP}_{25}$, which is selectively produced by Arctic sea-ice diatoms (Belt et al. 2007, Brown et al. 2014a) and has been successfully used as a proxy for sea iceassociated diets in benthic communities (Brown \& Belt 2012), crustaceans (Brown et al. 2017) and polar bears (Brown et al. 2018). In combination with planktonic-source HBIs, the 'H-Print' provides a means to estimate the relative proportions of sea ice- and phytoplankton-derived carbon within organisms (Brown \& Belt 2017). In addition to lipid-based proxies, the natural composition of bulk nitrogen and carbon stable isotopes can inform food web relationships. Nitrogen stable isotopes $\left(\delta^{15} \mathrm{~N}\right)$ experience an enrichment when moving up the food web from one trophic level to another (Minagawa \& Wada 1984), which allows evaluation of the trophic position of a consumer within the food web. The carbon isotopic signature $\left(\delta^{13} \mathrm{C}\right)$ of ice algae often differs from the phytoplankton isotopic composition due to varying $\mathrm{CO}_{2}$ levels between the semi-closed sea-ice system and the water column (Fry \& Sherr 1984, Hecky \& Hesslein 1995). Ice algae are often more enriched in ${ }^{13} \mathrm{C}$ (typically $\delta^{13} \mathrm{C}$ : -22 to $-13 \%$ ) compared to phytoplankton (typically $\delta^{13} \mathrm{C}$ : -28 to $-20 \%$ ) (Hobson et al. 1995, 2002, Tamelander et al. 2006, 2009). This isotopic difference is conservatively transferred along the marine food chain with only little enrichment from one trophic level to another (0.1 to $1 \%$ per trophic level) (DeNiro \& Epstein 1978, Post 2002).

In this study, we traced the trophic signal of primary-produced carbon through the benthic food web in Eclipse Sound in order to evaluate the importance of sea ice-derived carbon for benthic food web processes during spring 2018. We hypothesized that bot- 
tom-ice communities serve as an important carbon source in the study region, whereas pelagic processes play a minor role for benthic food web processes during spring. The results further our understanding of food web dynamics during the spring ice-covered period in the coastal Canadian Arctic, and are intended to inform vulnerability and impact assessments of sea-ice changes in this productive and socioeconomically important region.

\section{MATERIALS AND METHODS}

\subsection{Sample collection}

Sampling of bottom sea ice, surface waters, benthic invertebrates and sediments was carried out from 3 to 11 May 2018 along 2 transects in Eclipse Sound near Pond Inlet (Fig. 1, see Table 1). Bottom-ice samples were collected at 10 stations along a cross-section of Eclipse Sound. At each station, 6 ice cores were collected with a manual ice corer with a $9 \mathrm{~cm}$ interior diameter (Kovacs Enterprises). The bottom $5 \mathrm{~cm}$ of 5 cores were cut with a stainless steel handsaw and pooled together in an isothermal container, and brought back to the shore laboratory for further processing. The pooled sea-ice samples were melted in the dark with the addition of filtered seawater (500 ml per ice core; Whatman Nuclepore $0.22 \mu \mathrm{m}$ membrane filters), collected at the time of sampling to avoid osmotic stress for the algal cells during the melt process. One additional core was melted separately without the addition of seawater to determine salinity. Surface seawater was collected at 14 stations with a bilge pump by lowering the pump attached to a clean tygon tube to ca. $1 \mathrm{~m}$ below the ice bottom. Samples of melted bottom-ice cores and surface water were filtered onto pre-combusted Whatman GF/F filters $\left(6 \mathrm{~h}, 500^{\circ} \mathrm{C}\right)$ for later chlorophyll a ( $\mathrm{chl}$ a), FA, HBI and stable isotope (SI) analyses. All filters were stored at $-80^{\circ} \mathrm{C}$ until further processing, within 2 mo of sample collection. Benthic sediments and invertebrates (ophiuroids and polychaetes) were sampled at 4 coastal stations (Fig. 1, see Table 1) with a Ponar grab sampler. At each station, benthic invertebrates were picked and frozen separately in pre-combusted $(6 \mathrm{~h}$, $500^{\circ} \mathrm{C}$ ) clear Wheaton $25 \mathrm{ml}$ sample vials. The samples were frozen at $-80^{\circ} \mathrm{C}$ until further processing for chl a (sediments), FA, HBI and SI analyses.

Additionally, snow depth $(\mathrm{n}=6$, Stns 11 to $14: \mathrm{n}=$ 1), sea-ice thickness ( $\mathrm{n}=6$, not determined at Stns 11 to 14), freeboard (height of the sea-ice surface above the water level; $\mathrm{n}=6$, Stns 11 to $14: \mathrm{n}=1$ ), temperature at the snow surface $(\mathrm{n}=1)$ and ice surface $(\mathrm{n}=$ $1)$, and salinity of the bottom ice $(n=2)$ and/or surface waters $(n=2)$ were measured (see Table 1$)$.

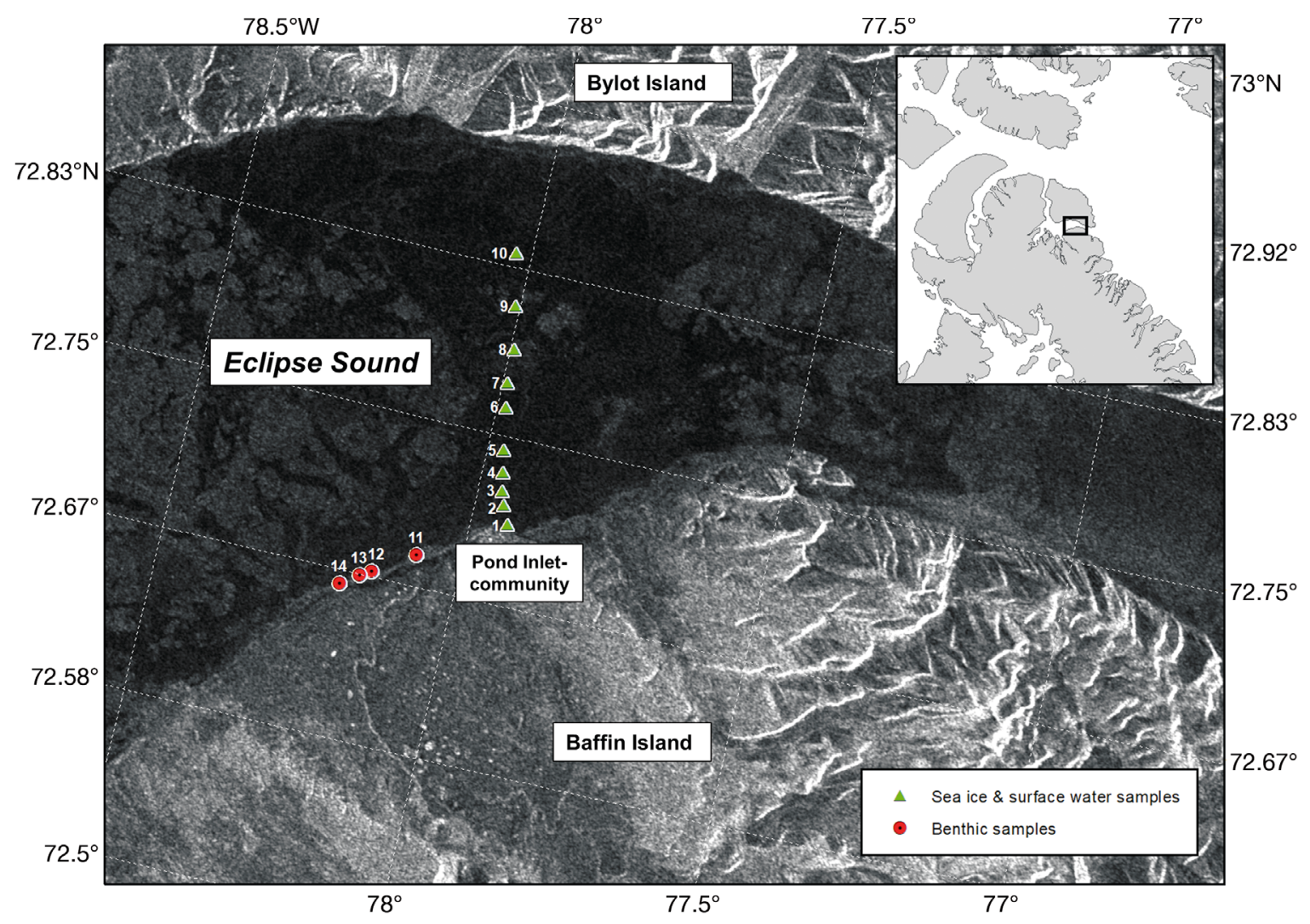

Fig. 1. Sampling area in Eclipse Sound, near the community of Pond Inlet in May 2018. Background image of RADARSAT-2 ScanSAR wide mode image acquired on 13 May 2018. () MacDonald, Dettwiler and Associates Ltd. 2018 - All Rights Reserved 


\subsection{Chl a}

Total chl a concentrations were determined fluorometrically on duplicate samples of melted bottom-ice cores (with added filtered seawater), surface water and sediments. Between 0.05 and 0.081 and between 0.75 and $1.25 \mathrm{l}$ of water was filtered onto $25 \mathrm{~mm}$ Whatman GF/F filters, for bottom-ice and surface water samples, respectively. Filtrations were carried out under low vacuum pressure (5 to $10 \mathrm{psi}$ ). Approximately $5 \mathrm{~g}$ of sediments (wet weight) were used for analyses. Pigments from filters and sediments were extracted ultrasound-assisted (Fisher Scientific) (Macías-Sánchez et al. 2009) in $90 \%$ acetone during $24 \mathrm{~h}$ at $5^{\circ} \mathrm{C}$ in the dark (Parsons et al. 1984). After the extraction period, chl a concentrations were measured with a Turner Designs 10AU fluorometer calibrated against pure chl a extract (Sigma Chemicals). Total chl a concentrations were calculated according to Parsons et al. (1984).

\subsection{FAs}

For FA analyses, between 0.25 and 0.501 and between 3.25 and 7.0 l of water was filtered through $47 \mathrm{~mm}$ Whatman GF/F filters for bottom-ice and surface water samples collected at Stns 1 to 10 , respectively.

Prior to lipid extraction, filters, benthic invertebrates and sediments were freeze-dried $\left(-50^{\circ} \mathrm{C}\right.$, 0.2 mbar, $24 \mathrm{~h}$ ). Whole individual organisms and sediments (approximately $1 \mathrm{~g}$ ) were homogenized with mortar and pestle. Total lipids were extracted with chloroform/methanol $(2: 1, \mathrm{v} / \mathrm{v})$ containing $0.01 \%$ butylated hydroxytoluene (Folch et al. 1957) and cleaned with $0.7 \%$ sodium chloride solution. Lipids were converted into fatty acid methyl esters (FAMEs) by transesterification in methanol containing $3 \%$ concentrated sulfuric acid at $50^{\circ} \mathrm{C}$ overnight. FAMEs were subsequently extracted with hexane, and separated on an Agilent Technologies 7890A gas chromatograph with a DB-23 capillary column (30 m, $0.25 \mathrm{~mm}$ i.d., $0.15 \mu \mathrm{m}$ film thickness) and a flame ionization detector operating at $350^{\circ} \mathrm{C}$, using a temperature program $\left(60\right.$ to $\left.200^{\circ} \mathrm{C}\right)$. Samples were injected split-less at $260^{\circ} \mathrm{C}$, and hydrogen was used as a carrier gas. Individual FAMEs were identified via FAME standard mixtures (Supelco 37 component FAME mix, Nu-Check GLC 455 and 463). FAMEs are reported as percent of total FA content in the shorthand nomenclature A:Bn-X, where A represents the number of carbon atoms, B refers to the number of double bonds and $\mathrm{n}-\mathrm{X}$ indicates the position of the unsaturation nearest to the methyl terminus. At each station, FA composition of the bottom ice was analyzed on triplicate samples (Stns 1, 2 and 8 on duplicates) (Fig. S1 in the Supplement at www.int-res.com/ articles/suppl/m627p033_supp.pdf; total $\mathrm{n}=27$ ), while surface waters (Fig. S2; total $\mathrm{n}=19$, Stn 3: single surface-water sample) and sediments (Fig. S3; total $n=8$ ) were analyzed on duplicate samples.

We investigated differences in relative FA proportions between the bottom ice and surface waters of the diatom-associated FAs 16:1n-7, 16:4n-1 and 20:5n-3 (Graeve et al. 1997, Falk-Petersen et al. 1998), and the dinoflagellate-associated FA 22:6n-3 (Graeve et al. 1994), which were also traced to benthic invertebrates and sediments. In addition to relative proportions of FAs, we investigated FA ratios, which may reflect the taxonomic composition of algal groups (Bergé \& Barnathan 2005). Diatoms produce higher amounts of C16 FAs and the FA 20:5n-3 in comparison to dinoflagellates, which biosynthesize C18 FAs and the FA 22:6n-3 in higher quantitates compared to diatoms (Dalsgaard et al. 2003, Bergé \& Barnathan 2005). Therefore, a dominance of diatomderived carbon can be indicated by high 16:1n-7/ 16:0, $\Sigma \mathrm{C} 16 / \Sigma \mathrm{C} 18$ and 20:5n-3/22:6n-3 ratios. The long-chain FAs 20:1 and 22:1 (all isomers) were used to indicate the presence of Calanus spp. in the diet of the benthic invertebrates. The importance of FAs of bacterial and terrestrial origin in primary producers and the benthic system was estimated from the relative proportions of iso- and anteiso-branched chain FAs and unbranched 15:0 and 17:0 (bacterial) and the proportions of $18: 2 \mathrm{n}-6$ and $18: 3 \mathrm{n}-3$ (terrestrial) (Dalsgaard et al. 2003; Kelly \& Scheibling 2012).

\subsection{HBIs}

Between 0.15 and 0.51 and between 3.5 and 6.31 of water was filtered onto $47 \mathrm{~mm}$ Whatman GF/F filters for bottom-ice (Stns 1 to 10) and surface water samples (Stns 6, 8, 10), respectively. Bottom-ice and surface water filters, whole benthic invertebrates and sediments were freeze-dried $\left(-50^{\circ} \mathrm{C}, 0.2\right.$ mbar, $\left.24 \mathrm{~h}\right)$, and homogenized with mortar and pestle (only invertebrates and sediments). Samples (dry weights: 13 to $24 \mathrm{mg}$ benthic invertebrates, $\sim 1 \mathrm{~g}$ sediment) were saponified with $20 \%$ potassium hydroxide in water/ methanol 1:9 (v/v) at $80^{\circ} \mathrm{C}$ for $1 \mathrm{~h}$ (Brown et al. 2018). HBIs were extracted subsequently with hexane, and fractionated using column chromatography with silica gel. HBIs were analyzed by gas chromatography- 
mass spectrometry (Agilent Technologies 7890B; 5977 MSD). The HBIs $\mathrm{IP}_{25}$ (specific mass to charge ratio $[\mathrm{m} / \mathrm{z}] 350.30)$, II $(\mathrm{m} / \mathrm{z} 348.3)$ and III $(\mathrm{m} / \mathrm{z} 346.3)$ were quantified via their mass spectral intensities in selective ion monitoring (SIM) mode to obtain relative abundances. To quantify the contribution of ice algae/ phytoplankton as a food source to the benthic system, the H-Print was determined from the intensities of the 3 HBIs in Eq. (1) (Brown et al. 2014b, Brown \& Belt 2017), and the proportion of sea icederived carbon was estimated as per Eq. (2) (Brown \& Belt 2017):

$$
\begin{gathered}
\text { H-Print }(\%)=\mathrm{III} /\left(\mathrm{IP}_{25}+\mathrm{II}+\mathrm{III}\right) \times 100 \\
\text { Sea ice-derived carbon }(\%)= \\
101.08-1.02 \times \text { H-Print }
\end{gathered}
$$

Filters and sediments were analyzed on duplicates (bottom ice: total $\mathrm{n}=19$, Stn 6: single bottom-ice sample; surface waters: total $n=5$, Stn 10: single surfacewater sample; sediments: total $\mathrm{n}=8$ ), and benthic invertebrates were analyzed on individual samples.

\subsection{SIs}

Between 0.15 and 0.51 and between 3.0 and 7.01 of water was filtered onto $47 \mathrm{~mm}$ Whatman GF/F filters for bottom-ice and surface water samples collected at Stns 1 to 10 , respectively. Prior to analysis, filters, benthic invertebrates and sediments were freezedried $\left(-50^{\circ} \mathrm{C}, 0.2 \mathrm{mbar}, 24 \mathrm{~h}\right)$. Invertebrates and sediments were homogenized with mortar and pestle, and samples were placed into tin capsules (benthic invertebrates: $\sim 0.4$ to $0.7 \mathrm{mg}$, sediments: $\sim 20 \mathrm{mg}$ ). Samples were analyzed with a continuous flow isotope ratio mass spectrometer (Delta V Plus; Thermo Scientific) interfaced with an elemental analyzer (ECS 4010; Costech Instruments) and connected via a Conflo IV interface (Thermo Scientific).

SI ratios are presented in delta $(\delta)$ notation: $\delta=$ $\left[\left(R_{\text {sample }} / R_{\text {standard }}\right)-1\right] \times 1000$, as \%o deviation from the primary (calibration) standards atmospheric nitrogen for nitrogen measurements $\left(\delta^{15} \mathrm{~N}\right)$ and Vienna Pee Dee Belemnite (VPDB) for carbon measurements $\left(\delta^{13} \mathrm{C}\right)$, respectively. True $\delta^{15} \mathrm{~N}$ and $\delta^{13} \mathrm{C}$ values were obtained after 2-point normalization (Paul et al. 2007). Accuracy and precision of isotopic measurements were verified by the certified reference material (International Atomic Energy Agency, IAEA) USGS40 $\left(\delta^{15} \mathrm{~N}=-4.52 \%, \delta^{13} \mathrm{C}=-26.39 \%\right)$ and USGS41a $\left(\delta^{15} \mathrm{~N}=47.55 \%, \delta^{13} \mathrm{C}=36.55 \%\right)$. Samples were analyzed on duplicates (bottom ice: total $\mathrm{n}=20$; surface waters: total $\mathrm{n}=16$, Stns 3, 4, 5 and 7: single surface water sample; benthic invertebrates: total $\mathrm{n}=$ 14 ) or triplicates (sediments: total $n=12$ ).

\subsection{Statistical analyses}

Correlation between bottom-ice chl a concentrations and sea-ice thickness as well as snow depth was tested using Pearson's correlation. Differences in chl a concentrations, FA proportions and SI compositions between the bottom ice and surface waters, and between ophiuroids and polychaetes were assessed using Student's $t$-tests. Variability in FA data sets was visualized with principal component analysis (PCA). A distance-based analysis of similarities (ANOSIM) was applied to test the overall variability among FA proportions in the bottom ice and surface waters, using a Euclidean distance matrix (Clarke \& Ainsworth 1993). Spatial variability in FA and SI compositions along the transect among the bottom ice and surface waters was assessed with 1-way ANOVAs followed by Tukey's HSD post hoc tests. A statistical threshold of $\leq=0.05$ was chosen, and results with $\mathrm{p} \leq$ 0.05 were considered significant. Prior to statistical analysis, the data were verified for normality of distribution. FA data were transformed applying an arcsine square root function to meet normality requirements for parametric statistics (Legendre \& Legendre 2012). All measures of statistical variation are reported as means $\pm 1 \mathrm{SD}$. All statistical analyses were run in R v.3.4.3 (R Core Team 2017).

\section{RESULTS}

\subsection{Sea-ice thickness and snow depth}

Sea-ice thickness ranged from 117.4 to $172.8 \mathrm{~cm}$ (Table 1), and varied between 2 and $10 \mathrm{~cm}(\mathrm{n}=5)$ within sampling sites $(\sim 1 \mathrm{~m}$ distance between coring locations at each sampling site). Snow depth varied between 6.7 and $13.0 \mathrm{~cm}$ along the cross-section stations, and between 12 and $23 \mathrm{~cm}$ at the coastal stations (Table 1). Difference in snow depth along the cross-section stations ranged from 0 to $4 \mathrm{~cm}(\mathrm{n}=5)$ within sampling sites.

\subsection{Chl a concentrations}

Bottom-ice chl a concentrations (438.2 $\pm 154.2 \mu \mathrm{g}$ $\left.\mathrm{l}^{-1}, 19.8 \pm 6.6 \mathrm{mg} \mathrm{m}^{-2}\right)$ were significantly higher than surface water chl a concentrations $\left(0.9 \pm 0.7 \mu \mathrm{g} \mathrm{l}^{-1}\right)$ at 


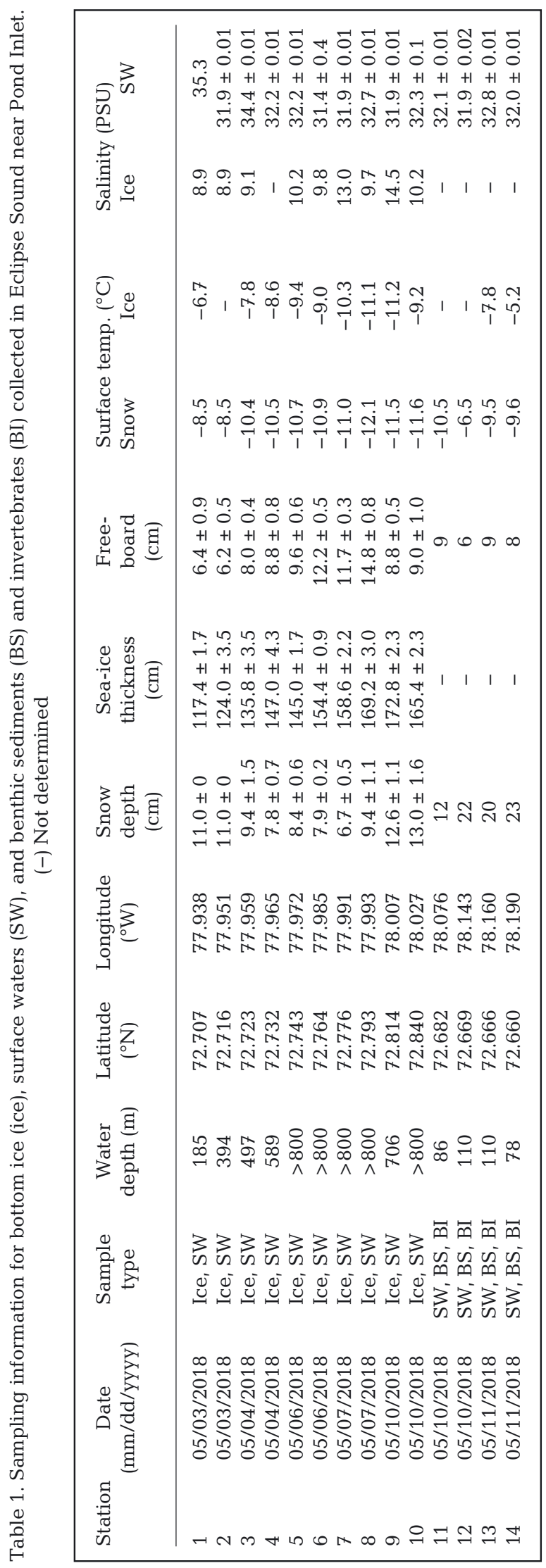

stations where ice biomass was collected ( $t$-test, $t=$ 8.9, $\mathrm{df}=9.0, \mathrm{n}=20, \mathrm{p} \leq 0.001$ ). Bottom-ice chl $a$ ranged from 185.8 to $615.5 \mu \mathrm{g} \mathrm{l}^{-1}$ (Table A1 in the Appendix). Surface water chl a ranged from 0.1 to $2.1 \mu \mathrm{g} \mathrm{l}^{-1}$ (Table A1). At the coastal stations, chl $a$ in surface waters ranged from 0.5 to $3.2 \mu \mathrm{g} \mathrm{l}^{-1}$. Both bottom-ice and surface water chl a values were the lowest at the coastal stations (Stns 1 and 2; Fig. 2). $\mathrm{Chl}$ a concentrations in the bottom ice were positively correlated with sea-ice thickness $(\mathrm{R}=0.76, \mathrm{n}=$ $10, p=0.011$ ). There was no significant correlation between bottom-ice chl $a$ and snow depth $(R=-0.07$, $\mathrm{n}=10, \mathrm{p}=0.85)$. Chl $\mathrm{a}$ in the sediments ranged from 0.1 to $0.5 \mathrm{\mu g} \mathrm{g}^{-1}$ wet weight, and reflected the trend of surface water chl a concentrations with the lowest values at Stn 13 and the highest at Stn 14 along the coastal transect (Table A1).

\subsection{FA compositions}

A total of 48 FAs were identified in surface waters and 42 were identified in the bottom sea ice; 23 were polyunsaturated (PUFAs), similarly for bottom ice and surface waters. As visualized in the PCA, the FA profiles of the bottom ice and surface waters differed strongly (Fig. 3). Bottom ice had high proportions of the diatom-associated FAs 16:1n-7, 16:4n-1 and other C16 FAs (Fig. 3, Table 2). These FAs represented 70.0 $\pm 3.7 \%$ of total FAs in the bottom ice compared to 48.7 $\pm 11.0 \%$ in surface waters. The relative abundances of the diatom-associated marker FAs 16:1n-7, 16:4n-1 and 20:5n-3 were significantly higher in the bottom

\section{Bottom ice}

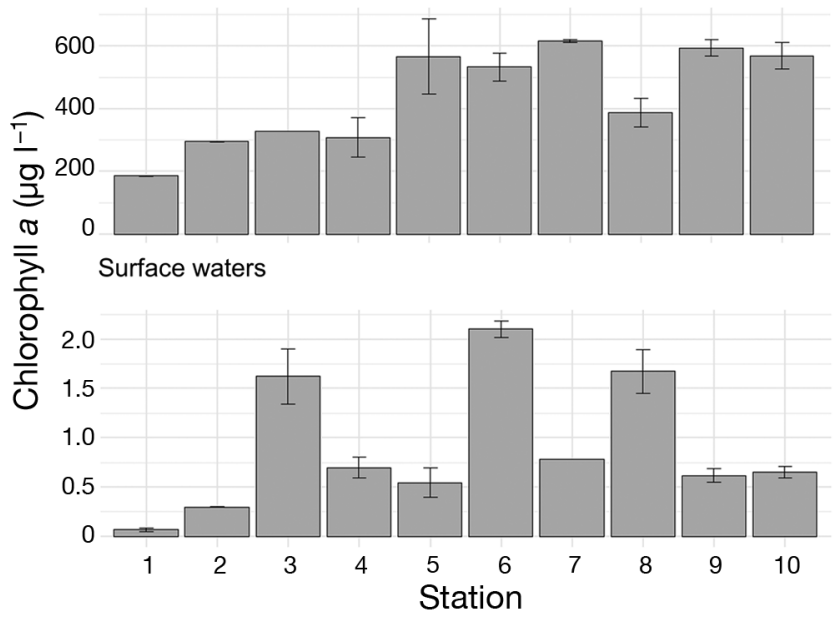

Fig. 2. Chlorophyll a concentrations (mean $\pm 1 \mathrm{SD}$ ) in the bottom-ice and surface water samples collected during May 2018 in Eclipse Sound 


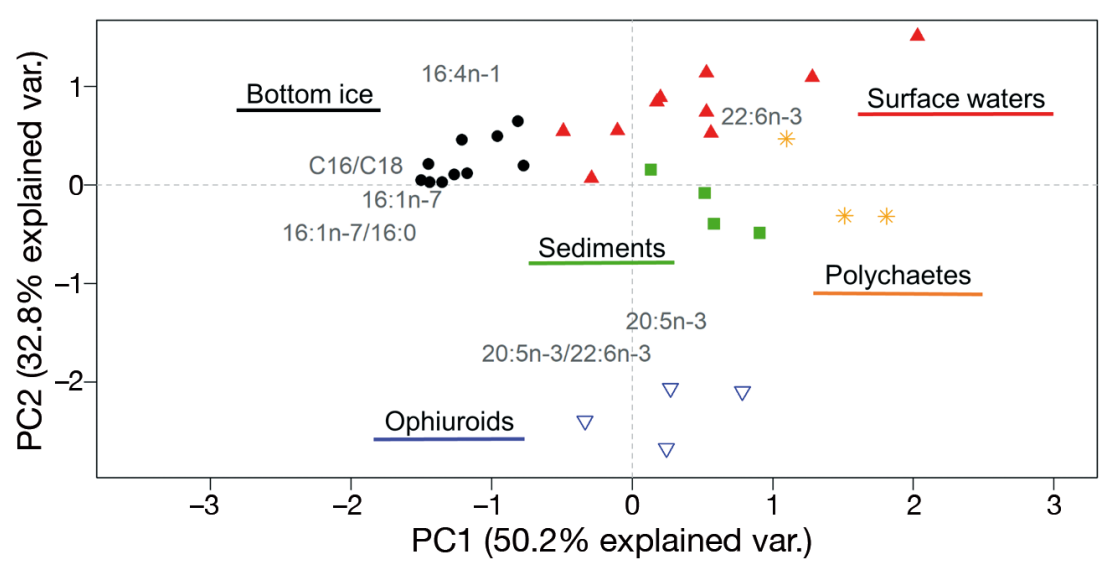

Fig. 3. Principal component analysis of the diatom-associated marker fatty acids (FAs) 16:1n-7, 16:4n-1 and 20:5n-3, the dinoflagellate-associated marker FA 22:6n-3, and the marker FA ratios 16:1n-7/16:0, $\Sigma \mathrm{C} 16 / \Sigma \mathrm{C} 18$ and 20:5n-3/22:6n-3 in the bottom-ice, surface waters, benthic invertebrates and sediment samples collected during May 2018 in Eclipse Sound surface waters, the first 2 principal components of the PCA explained $96.5 \%$ of the variance in FA proportions between the stations (Fig. 4b). Surface waters from the coastal stations (Stns 1 and 2) were distinct from the other locations based on their significantly higher proportions of 18:0 (ANOVA, $F_{9,9}=16.7, \mathrm{n}=19, \mathrm{p} \leq 0.001$, Tukey's HSD $\mathrm{p} \leq 0.05$ ), with lower proportions of all 3 diatom-associated FAs, and lower ratios of $16: 1 \mathrm{n}-7 / 16: 0$ and $\Sigma$ C16/ $\Sigma$ C18 (both $<1$ ) compared to all other stations. All other stations showed FA ratios well above 1 (Table S2).

The FA profiles of ophiuroids and polychaetes were clearly distinct (Fig. 3), and differed predominantly in their relative proportions of the diatom-associ- ice than in the surface waters (Table 2). The FA distribution in surface waters was characterized by higher proportions of C18 FAs $(28.3 \pm 12.8 \%$ of total FAs $)$ compared to the bottom ice $(6.5 \pm 1.1 \%$ of total FAs $)$. Mean proportions of the dinoflagellate-associated FA 22:6n-3 were $<2 \%$ in both the bottom ice and surface waters. The FA ratios 16:1n-7/16:0, $\Sigma$ C16/ $\Sigma$ C18 and 20:5n-3/22:6n-3 were significantly higher in the bottom ice compared to surface waters. Relative proportions of bacterial FAs were significantly higher in surface waters compared to the bottom ice (Table 2).

There was high variability in FA composition in both the bottom ice (ANOSIM, $\mathrm{R}=0.784, \mathrm{p}=0.001)$ and surface waters (ANOSIM, R $=0.594, p=0.001$ ). The first 2 principal components of the PCA explained $96.0 \%$ of the variance in the bottom-ice FAs (Fig. 4a). Bottom ice from Stns 1,8 and 10 were grouped together based on their significantly lower proportions of $16: 1 \mathrm{n}-7$, but higher proportions of 16:4n-1 compared to the other stations (ANOVA, $F_{9,17}=53.9, \mathrm{n}=27, \mathrm{p} \leq 0.001$, Tukey's HSD $\mathrm{p} \leq 0.01$; ANOVA, $F_{9,17}=$ 23.8, $\mathrm{n}=27, \mathrm{p} \leq 0.001$, Tukey's HSD $\mathrm{p} \leq$ 0.05 , respectively) (Table S1). The FA ratios of $\Sigma C 16 / \Sigma C 18$ and $20: 5 n-3 / 22: 6 n-3$ were lower at Stns 1, 8 and 10 compared to most other stations (ANOVA, $F_{9,17}=4.4$, $\mathrm{n}=27, \mathrm{p} \leq 0.01$, Tukey's HSD $\mathrm{p} \leq 0.05$; ANOVA, $F_{9,17}=14.9, \mathrm{n}=27, \mathrm{p} \leq 0.001$, Tukey's HSD $\mathrm{p} \leq 0.05$, respectively). In
Table 2. Relative proportions of fatty acids (FAs) (mean $\pm 1 \mathrm{SD}$ ) with mean contributions $\geq 1 \%$ to the total FA content in the bottom ice and/or surface waters, marker FA ratios, and proportions of saturated (SFAs), monounsaturated (MUFAs) and polyunsaturated FAs (PUFAs) in samples collected during May 2018 in Eclipse Sound. ns: not significant

\begin{tabular}{|c|c|c|c|c|c|}
\hline \multirow{2}{*}{ Fatty acid } & \multicolumn{2}{|c|}{ FA relative contribution ( $\%)$} & \multirow[b]{2}{*}{$\mathrm{df}$} & \multirow{2}{*}{$\begin{array}{c}t \text {-test } \\
t\end{array}$} & \multirow[b]{2}{*}{$\mathrm{p} \leq$} \\
\hline & $\begin{array}{l}\text { Bottom ice } \\
(\mathrm{n}=10)\end{array}$ & $\begin{array}{l}\text { Surface waters } \\
\qquad(\mathrm{n}=10)\end{array}$ & & & \\
\hline $14: 0$ & $10.7 \pm 1.9$ & $9.1 \pm 2.4$ & & ns & \\
\hline $16: 0$ & $19.0 \pm 1.1$ & $18.3 \pm 2.1$ & & ns & \\
\hline $16: 1 n-7$ & $42.3 \pm 4.8$ & $23.7 \pm 9.5$ & 11.8 & 5.0 & 0.001 \\
\hline $16: 2 n-4$ & $2.5 \pm 0.5$ & $1.6 \pm 0.5$ & 17.6 & 4.1 & 0.001 \\
\hline $16: 4 n-1$ & $3.3 \pm 0.7$ & $2.0 \pm 0.9$ & 13.6 & 3.5 & 0.01 \\
\hline $18: 0$ & $0.6 \pm 0.2$ & $12.3 \pm 12.6$ & 9.1 & 4.7 & 0.001 \\
\hline $18: 1 n-9$ & $1.1 \pm 0.3$ & $2.5 \pm 0.5$ & 16.7 & 8.3 & 0.001 \\
\hline $18: 1 n-7$ & $0.3 \pm 0.2$ & $1.6 \pm 0.7$ & 13.5 & 7.1 & 0.001 \\
\hline $18: 3 n-1$ & $0.4 \pm 0.2$ & $2.4 \pm 1.1$ & 13.7 & 7.6 & 0.001 \\
\hline $18: 4 n-1$ & $1.6 \pm 0.4$ & $1.5 \pm 0.4$ & & ns & \\
\hline $20: 5 n-3$ & $9.3 \pm 1.9$ & $6.9 \pm 1.7$ & 17.6 & 3.0 & 0.01 \\
\hline $22: 6 n-3$ & $1.2 \pm 0.6$ & $1.8 \pm 1.0$ & & ns & \\
\hline $16: 1 n-7 / 16: 0$ & $2.2 \pm 0.2$ & $1.3 \pm 0.5$ & 9.9 & 4.8 & 0.001 \\
\hline$\Sigma \mathrm{C} 16 / \Sigma \mathrm{C} 18$ & $12.4 \pm 2.1$ & $2.2 \pm 1.2$ & 17.0 & 12.7 & 0.001 \\
\hline $20: 5 n-3 / 22: 6 n-3$ & $8.3 \pm 2.2$ & $4.0 \pm 1.8$ & 17.7 & 4.8 & 0.001 \\
\hline Bacterial FAs & $0.9 \pm 0.4$ & $2.4 \pm 1.3$ & 10.7 & 2.5 & 0.05 \\
\hline Terrestrial FAs & $0.6 \pm 0.1$ & $0.8 \pm 0.2$ & 11.4 & 2.7 & 0.05 \\
\hline SFAs & $31.3 \pm 1.9$ & $42.5 \pm 10.0$ & 9.8 & 3.6 & 0.01 \\
\hline MUFAs & $48.3 \pm 4.1$ & $32.4 \pm 7.2$ & 13.4 & 5.8 & 0.001 \\
\hline PUFAs & $20.3 \pm 5.6$ & $25.1 \pm 4.8$ & & $\mathrm{~ns}$ & \\
\hline
\end{tabular}


a) Bottom ice

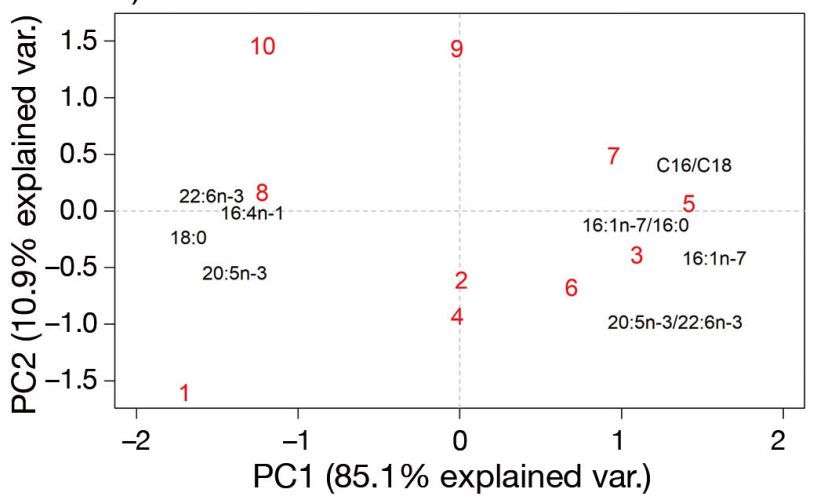

b) Surface waters

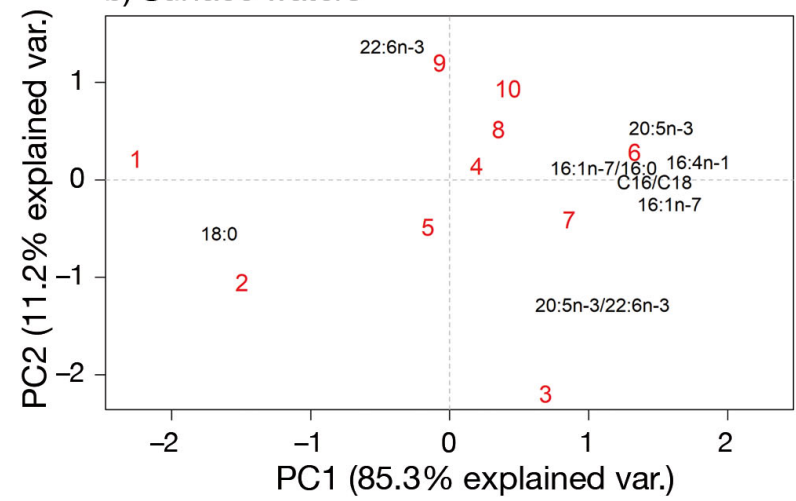

Fig. 4. Principal component analysis of the diatom-associated marker fatty acids (FAs) $16: 1 \mathrm{n}-7,16: 4 \mathrm{n}-1$ and $20: 5 \mathrm{n}-3$, the dinoflagellate-associated marker FA 22:6n-3, and the marker FA ratios 16:1n-7/16:0, $\Sigma$ C16/ $\Sigma$ C18 and 20:5n-3/22:6n-3 in

(a) bottom-ice and (b) surface water samples collected during May 2018 in Eclipse Sound at stations 1 to 10

22:1n-11 and 22:1n-9 suggested the presence of Calanus spp. in the invertebrates' diets, with higher proportions of these FAs in polychaetes compared to ophiuroids (Tables 3 \& S3). Relative proportions of

Table 3. Relative proportions of fatty acids (FAs) (mean \pm 1 SD) with mean contributions $\geq 1 \%$ to the total FA content in benthic invertebrates and/or sediments, marker FA ratios, and proportions of saturated (SFAs), monounsaturated (MUFAs) and polyunsaturated FAs (PUFAs) in samples collected during May 2018 in Eclipse Sound. Statistical results are from the comparison between ophiuroids and polychaetes. (-) Not determined; ns: not significant

\begin{tabular}{|c|c|c|c|c|c|c|}
\hline \multirow[t]{2}{*}{ Fatty acid } & \multirow[b]{2}{*}{$\begin{array}{c}\text { Ophiuroids } \\
(\mathrm{n}=4)\end{array}$} & \multicolumn{4}{|c|}{ FA relative contribution $(\%)$} & \multirow[b]{2}{*}{$\begin{array}{l}\text { Sediments } \\
\quad(\mathrm{n}=4)\end{array}$} \\
\hline & & $\begin{array}{l}\text { Polychaetes } \\
\quad(\mathrm{n}=3)\end{array}$ & df & $t$ & $\mathrm{p} \leq$ & \\
\hline $14: 0$ & $7.5 \pm 0.5$ & $4.4 \pm 0.5$ & 3.7 & 7.9 & 0.01 & $6.5 \pm 1.1$ \\
\hline 14:0 anteiso & - & - & & - & & $2.2 \pm 0.9$ \\
\hline $15: 0$ & $0.4 \pm 0.1$ & $0.6 \pm 0.1$ & & ns & & $1.6 \pm 0.5$ \\
\hline $16: 0$ & $11.9 \pm 1.8$ & $9.7 \pm 1.4$ & & $\mathrm{~ns}$ & & $18.3 \pm 3.0$ \\
\hline $16: 1 n-7$ & $23.1 \pm 6.7$ & $12.5 \pm 2.4$ & 4.4 & 2.9 & 0.05 & $25.1 \pm 5.1$ \\
\hline $17: 0$ iso & $1.7 \pm 1.3$ & $2.4 \pm 1.4$ & & ns & & $1.3 \pm 1.4$ \\
\hline $18: 0$ & $3.6 \pm 0.9$ & $3.1 \pm 0.2$ & & ns & & $5.8 \pm 3.3$ \\
\hline $18: 1 n-9$ & $2.6 \pm 0.5$ & $1.9 \pm 1.3$ & & ns & & $3.4 \pm 1.2$ \\
\hline $18: 1 n-7$ & $6.0 \pm 0.9$ & $9.1 \pm 4.7$ & & ns & & $4.1 \pm 1.1$ \\
\hline $18: 3 n-1$ & $0.4 \pm 0.2$ & $0.1 \pm 0.1$ & & ns & & $1.7 \pm 0.5$ \\
\hline $20: 1 n-11$ & $2.9 \pm 1.6$ & $7.1 \pm 1.0$ & 4.9 & 4.1 & 0.01 & $0.4 \pm 0.5$ \\
\hline $20: 1 n-9$ & $1.3 \pm 0.4$ & $2.0 \pm 1.9$ & & ns & & $0.1 \pm 0.2$ \\
\hline $20: 4 n-6$ & $1.6 \pm 3.1$ & $0.9 \pm 0.9$ & & ns & & $1.8 \pm 0.3$ \\
\hline $20: 5 n-3$ & $17.9 \pm 2.1$ & $18.0 \pm 8.6$ & & $\mathrm{~ns}$ & & $8.1 \pm 1.6$ \\
\hline $22: 1 n-11$ & $3.6 \pm 1.1$ & $4.3 \pm 5.0$ & & ns & & - \\
\hline $22: 1 n-9$ & $1.1 \pm 0.2$ & $0.6 \pm 0.9$ & & ns & & $1.0 \pm 0.6$ \\
\hline $22: 6 n-3$ & $0.4 \pm 0.3$ & $6.4 \pm 1.8$ & 4.4 & 6.6 & 0.01 & $0.9 \pm 1.4$ \\
\hline $24: 0$ & - & - & & - & & $2.8 \pm 1.1$ \\
\hline $16: 1 n-7 / 16: 0$ & $1.9 \pm 0.4$ & $1.3 \pm 0.4$ & & $\mathrm{~ns}$ & & $1.4 \pm 0.5$ \\
\hline$\Sigma \mathrm{C} 16 / \Sigma \mathrm{C} 18$ & $2.1 \pm 0.6$ & $1.4 \pm 0.2$ & & ns & & $2.0 \pm 0.3$ \\
\hline $20: 5 n-3 / 22: 6 n-3$ & $30.3 \pm 10.4$ & $2.7 \pm 0.7$ & 3.3 & 7.1 & 0.01 & $6.1 \pm 1.9$ \\
\hline Bacterial FAs & $3.7 \pm 2.3$ & $3.5 \pm 0.9$ & & ns & & $3.3 \pm 2.0$ \\
\hline Terrestrial FAs & $0.4 \pm 0.1$ & $0.5 \pm 0.2$ & & $\mathrm{~ns}$ & & $1.0 \pm 0.8$ \\
\hline SFAs & $26.9 \pm 0.9$ & $18.4 \pm 4.5$ & 2.5 & 3.7 & 0.05 & $41.5 \pm 10.1$ \\
\hline MUFAs & $47.8 \pm 5.4$ & $51.4 \pm 10.9$ & & ns & & $38.7 \pm 6.3$ \\
\hline PUFAs & $25.4 \pm 4.8$ & $30.3 \pm 6.8$ & & ns & & $19.9 \pm 4.1$ \\
\hline
\end{tabular}

SFAs were significantly higher in ophiuroids than polychaetes. The FA profile of sediments was characterized by high proportions of the diatom-associated FAs $16: 1 n-7$ and 20:5n-3 and FA ratios $>1$, with low proportions of the dinoflagellate-associated marker FA 22:6n-3. Relative proportions of the diatom-associated FA 16:4n-1, however, were very low $(<0.5 \%)$ (Tables $3 \& \mathrm{~S} 3)$.

\subsection{HBI compositions}

In both the bottom sea ice and surface waters, II had the highest and III had the lowest mean relative contributions to the overall HBI content (Table 4). Along the cross-section stations, the estimates of relative proportions of sea ice-derived carbon in the bottom ice ranged from 70 to $97 \%$ (Table A2), and varied between 88 and $96 \%$ in surface waters. In both benthic invertebrates and sediments, II had higher mean relative contributions to the overall HBI content compared to $\mathrm{IP}_{25}$ and III. At the coastal stations, relative proportions of sea ice-derived carbon in the benthic community ranged from 70 to $87 \%$ (Table 4 ).

\subsection{SI compositions}

There was no significant difference in $\delta^{15} \mathrm{~N}$ values between the 
Table 4. Relative contributions (mean $\pm 1 \mathrm{SD}$ ) of the different highly branched isoprenoids and estimated relative contributions of sea ice-derived carbon in the bottom ice, surface water, benthic invertebrate and sediment samples collected during May 2018 in Eclipse Sound. Proportions of III are equivalent to the H-Print. See Section 2.4 for details on estimates of sea ice-derived carbon contributions

\begin{tabular}{|lccccc|}
\hline Sample type & $\mathrm{n}$ & $\mathrm{IP}_{25}(\%)$ & $\mathrm{II}(\%)$ & $\begin{array}{c}\mathrm{III}(=\mathrm{H}-\mathrm{Print}) \\
(\%)\end{array}$ & $\begin{array}{c}\text { Sea ice-derived } \\
\text { carbon }(\%)\end{array}$ \\
\hline Bottom ice & 10 & $35.9 \pm 3.9$ & $49.7 \pm 8.6$ & $14.3 \pm 7.4$ & $86.5 \pm 7.6$ \\
Surface waters & 3 & $41.1 \pm 6.4$ & $50.2 \pm 4.9$ & $8.7 \pm 3.9$ & $92.2 \pm 3.9$ \\
Ophiuroids & 3 & $27.5 \pm 1.8$ & $49.0 \pm 4.3$ & $23.5 \pm 6.0$ & $77.1 \pm 6.1$ \\
Polychaetes & 1 & 35.2 & 42.1 & 22.8 & 77.9 \\
Sediments & 4 & $40.8 \pm 1.5$ & $43.4 \pm 1.3$ & $15.9 \pm 1.7$ & $84.9 \pm 1.7$ \\
\hline
\end{tabular}

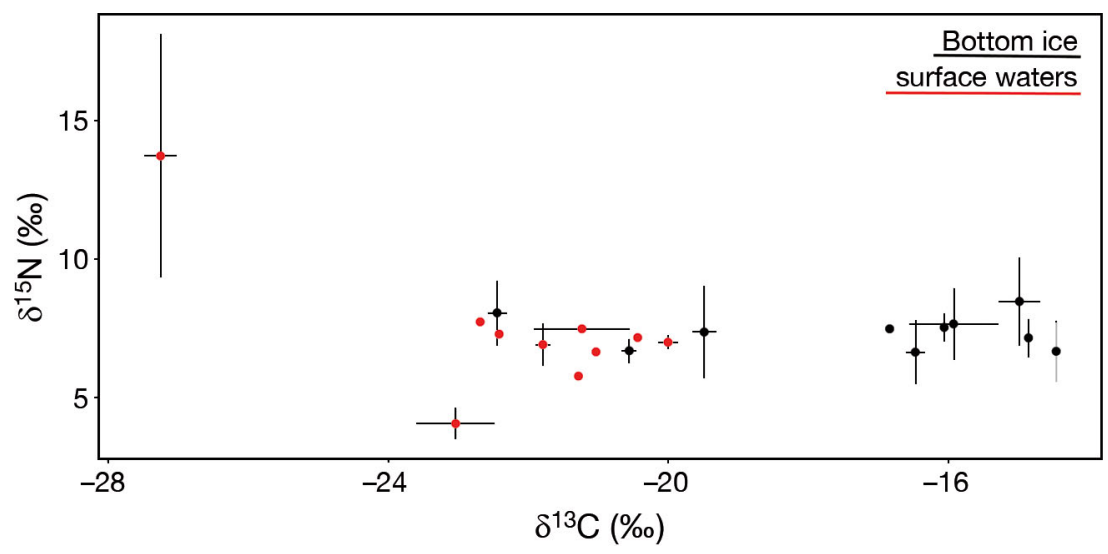

Fig. 5. Stable isotope values of nitrogen $\left(\delta^{15} \mathrm{~N}\right)$ and carbon $\left(\delta^{13} \mathrm{C}\right)$ in the bottom-ice and surface water samples collected during May 2018 in Eclipse Sound. In the surface waters from Stn $2, \delta^{13} \mathrm{C}$ values were significantly lower compared to all other stations (ANOVA, $F_{9,6}=54.1, \mathrm{n}=16, \mathrm{p} \leq 0.001$, Tukey's HSD $\mathrm{p} \leq 0.001$ )

$6.6 \mathrm{mg} \mathrm{m}^{-2}$ ) were in a similar range as bottom-ice chl a concentrations in landfast first-year sea ice in other coastal locations of the Canadian Arctic during the same period (Allen Bay: up to $28 \mathrm{mg} \mathrm{m}^{-2}$, Campbell et al. 2014; Franklin Bay: up to $\sim 500 \mu \mathrm{g} \mathrm{l}^{-1}$, Riedel et al. 2006; Amundsen Gulf: up to $\sim 50 \mathrm{mg} \mathrm{m} \mathrm{m}^{-2}$, Brown et al. 2011). Considerably higher chl a values in landfast first-year sea ice from Resolute Passage during the same period (up to >100 mg chl a m $\mathrm{m}^{-2}$ Michel et al. 1996, Mundy et al. 2007) might, on the one hand, be an indicator for the particularly high productivity in Resolute Passage (Smith et al. 1988, Welch \& Bergmann 1989) but could also, on the other hand, suggest that maximal chl $a$ in the bottom ice may not have been reached yet during our sampling campaign. This is supported by the relatively low levels of PUFAs in the bottom-ice (mean 20.3\%), as PUFAs can reach relative proportions of $>40 \%$ in plankton during the spring bloom according to studies in Conception Bay (Parrish et al. 2005) and high-Arctic Svalbard (Leu et al. 2006, 2010). Bottom-ice chl a concentrations were highly variable between the stations in our study, ranging from

bottom sea ice and surface waters. In contrast, $\delta^{13} \mathrm{C}$ values were significantly higher in the bottom ice than surface waters ( $t$-test, $t=4.6, \mathrm{df}=16.8, \mathrm{n}=20, \mathrm{p}$ $\leq$ 0.001) (Fig. 5, Table 5).

Values of $\delta^{15} \mathrm{~N}$ were significantly higher in polychaetes than ophiuroids, ranging from 11.2 to $12.1 \%$ and from 9.0 to $10.5 \%$, respectively ( $t$-test, $t=4.9$, $\mathrm{df}=5.0, \mathrm{n}=7, \mathrm{p} \leq 0.01$ ) (Table 5). In contrast, $\delta^{13} \mathrm{C}$ values were significantly higher in ophiuroids than polychaetes $(-12.7$ to $-10.1 \%$ versus -20.1 to $-18.9 \%$, respectively) ( $t$-test, $t=10.1, \mathrm{df}=4.3, \mathrm{n}=7$, $\mathrm{p} \leq 0.001)$. The $\delta^{15} \mathrm{~N}$ values in sediments varied between 5.5 and $6.7 \%$. Sediment $\delta^{13} \mathrm{C}$ values ranged from -15.9 to $-12.4 \%$, and were in between $\delta^{13} \mathrm{C}$ values in ophiuroids and polychaetes (Table 5).

\section{DISCUSSION}

During our sampling period, chl a concentrations within the bottom ice $\left(438.2 \pm 154.2 \mu \mathrm{g} \mathrm{l} \mathrm{l}^{-1}, 19.8 \pm\right.$ 185.8 to $615.5 \mu \mathrm{g} \mathrm{l}^{-1}$ (7.9 to $28.0 \mathrm{mg} \mathrm{m}^{-2}$ ). The distribution of ice algal biomass is patchy (Cimoli et al. 2017), reflecting the impact of e.g. surface snow-depth and ice thickness and environmental variables on the seaice algae primary production (Mundy et al. 2005, Juhl $\&$ Krembs 2010). The high variability in bottom-ice chl a was unlikely the result of differences in snow depths, as they varied in a narrow range along the

Table 5. Stable isotope values of nitrogen $\left(\delta^{15} \mathrm{~N}\right)$ and carbon $\left(\delta^{13} \mathrm{C}\right)$ (mean $\left.\pm 1 \mathrm{SD}\right)$ in the bottom-ice, surface water, benthic invertebrate and sediment samples collected during May 2018 in Eclipse Sound. (-) Not determined

\begin{tabular}{|lrrc|}
\hline Sample type & $\mathrm{n}$ & $\delta^{15} \mathrm{~N}(\%)$ & $\delta^{13} \mathrm{C}(\%)$ \\
\hline Bottom ice & 10 & $7.4 \pm 0.6$ & $-17.2 \pm 2.7$ \\
Surface waters & 10 & $7.4 \pm 2.5$ & $-22.1 \pm 2.2$ \\
Ophiuroids & 4 & $9.5 \pm 0.7$ & $-11.6 \pm 1.4$ \\
Polychaetes & 3 & $11.7 \pm 0.5$ & $-19.6 \pm 0.6$ \\
Sediments & 4 & $6.1 \pm 0.5$ & $-13.5 \pm 1.6$ \\
\hline
\end{tabular}


sampling transect (max. difference $\sim 6 \mathrm{~cm}$ between Stns 7 and 10). Chl a values in the bottom ice were positively correlated with sea-ice thickness; however, in comparison to snow depth, ice thickness is not a major controlling factor for sea-ice chl a due to its lower impact on light transmission through the ice (Gosselin et al. 1986). The differences in ice thickness (max. difference $\sim 55 \mathrm{~cm}$ between Stns 1 and 7) might therefore not have contributed to a significant difference in light availability for algal growth at the bottom of the sea ice. Bottom-ice chl a concentrations were generally higher at stations with greater depths, but there was no definite association apparent for surface water chl $a$, which might be explained by the more dynamic character of water column phytoplankton compared to ice algae with a more restricted range of motion. A positive correlation of bottom-ice chl a and water depth could possibly reflect a link between deep water nutrient pools and upward mixing of nutrients to the sea ice-water interface (Cota et al. 1987).

Both primary producer communities within the seaice bottom and surface waters were dominated by diatom-produced FAs versus dinoflagellate-produced FAs. Derived from the H-Print, the relative proportions of sea ice diatom-derived carbon (versus phytoplankton diatom-derived carbon) were similar between the bottom-ice and surface water samples (mean 87 and 92\%, respectively), suggesting that most of the diatom component of the water column community likely originated from the sea ice, rather than there being any significant under-ice phytoplankton bloom in the region during sampling. During our sampling, softer and more porous ice conditions (Campbell et al. 2015) might have caused enhanced exchange of bottom-ice algal material with the underlying water column. However, chl a concentrations in surface waters were 2 orders of magnitude lower than in the bottom-ice, indicating that sea-ice diatoms were more dispersed and of lower overall density in surface waters compared to the bottom sea-ice. The low relative proportions of the dinoflagellate-associated FA 22:6n-3 in the bottom ice and surface waters (mean $<2 \%$ ) suggest that dinoflagellates were of minor importance in both communities. Dietary input from vascular plants, which can contribute significantly to benthic food webs (Kelly \& Scheibling 2012), was low in our study, based on low proportions of the terrestrial marker FAs in the bottom ice, surface waters and the benthic system (mean $\leq 1 \%$ ) (Harwood \& Russell 1984). During our sampling period, advanced snow melt on land had not yet occurred, and therefore terrestrial runoff would still have been low.
Based on FA profiles, the H-Print and the high $\delta^{13} \mathrm{C}$ values, ophiuroids and polychaetes largely relied on sea ice-derived carbon to supply energy to the benthic system. It must be taken into consideration, however, that benthic invertebrates are able to modify their dietary FAs, and modifications by lipid-rich tissue may influence the FA composition due to the lack of specific lipid-storage organs in many benthic species (Kelly \& Scheibling 2012). The $\delta^{13} \mathrm{C}$ values in ophiuroids were strongly enriched, and significantly higher than in polychaetes. This is in agreement with the findings in other Arctic food web studies (Hobson et al. 2002, Tamelander et al. 2006), and the higher proportions of diatom-associated FAs in the FA pool of the ophiuroids compared to polychaetes here. It has been proposed that enriched $\delta^{13} \mathrm{C}$ values in benthic invertebrates can point to a strong interaction with the microbial food web (Lovvorn et al. 2005, Iken et al. 2010). In our study, the low bacterial FA proportions (mean $<4 \%$ ) and high H-Prints indicate that the $\delta^{13} \mathrm{C}$ values in invertebrates reflected the assimilation of sea ice-derived carbon sources rather than a dependency on bacterial-produced carbon. $\delta^{13} \mathrm{C}$ values in ophiuroids are subject to large spatiotemporal variability, as the ophiuroids from the Northeast Water Polynya, the Canada Basin and the Bering Sea had $\delta^{13} \mathrm{C}$ values in the range $\sim-24$ to $-18 \%$ o (Hobson et al. 1995, Iken et al. 2005, Lovvorn et al. 2005), which are considerably more depleted than the individuals in our study $(-11.6 \pm 1.4 \%$ o). Such variations might be due to the inconsistent availability of certain carbon sources, as well as geographic variations in source carbon, along with the opportunistic feeding behavior of ophiuroids and other benthic species (Warner 1982, Graeve et al. 1997). Higher proportions of copepod-associated FAs as well as higher $\delta^{15} \mathrm{~N}$ values suggest a higher degree of carnivory in polychaetes compared to ophiuroids, which is in agreement with previous studies (Fry 1988, Iken et al. 2005). A stronger dependency on drifting copepods or their remains potentially carrying a regionally different biomarker signal than copepods in the sampling region could help explain the isotopic difference of $\sim 8 \%$ o between ophiuroids and polychaetes, if it is assumed that the copepods' carbon signal was transferred to polychaetes rather than ophiuroids. The potentially higher mobility of polychaetes compared to ophiuroids could have further influenced their stable isotope composition, reflecting geographical differences in carbon source compositions. However, the comparably high sea-ice carbon values in these species, derived from HBI lipids (77 and $78 \%$ ), indicate that both herbivory and 
carnivory were underpinned, either directly or indirectly, by sea-ice carbon during this time.

The extent of sedimentation and grazing of organic material is subject to large spatio-temporal variability, itself dependent on multiple environmental and ecological factors (e.g. Caron et al. 2004, Sejr et al. 2007). In ice-covered Arctic regions in spring, a large proportion of ice algae released from the sea ice during melt can reach the seafloor (Fortier et al. 2002, Michel et al. 2002, Boetius et al. 2013), particularly in shallow regions where the benthic samples were collected. Integrated over the first $20 \mathrm{~m}$ of the water column, water chl a concentrations $\left(\sim 18 \mathrm{mg} \mathrm{m}^{-2}\right)$ were comparable to bottom-ice chl a concentrations of $\sim 20 \mathrm{mg} \mathrm{m}^{-2}$. However, sea-ice algae are locally more heavily concentrated than phytoplankton, and fastsinking large ice algal aggregates (Michel et al. 1993, Haecky et al. 1998, Boetius et al. 2013) can be more readily accessible for benthic grazers than phytoplankton. Our results of a high volumetric algal biomass in the bottom sea ice versus low volumetric algal biomass in surface waters, and a strong sea ice-diatom fingerprint in the benthic samples support the assumption that sea ice-derived carbon is likely important (at least) as an early season food source for benthic communities in the study region. Strong sea ice-benthic coupling has been described on Canadian shelves and constitutes an important trophic pathway for sea ice-algae biomass towards higher trophic levels (Renaud et al. 2007, Juul-Pedersen et al. 2008).

The landfast ice in Pond Inlet has experienced a significant decline in ice duration over the past decades (Galley et al. 2012). Earlier sea-ice melt can impact the productivity of ice-algal communities and their coupling to pelagic and benthic grazers (Fortier et al. 2002, CAFF 2013, Wassmann \& Reigstad 2011). Longer open-water seasons can create a challenge for highly sea ice-dependent benthic species (Brown \& Belt 2012), when timing and availability of ice algae are negatively impacted by changes to the seaice system (Piepenburg 2005) despite potentially increased water column productivity as a result of thinning sea ice (Arrigo et al. 2012, Assmy et al. 2017). Moreover, in the Canadian Archipelago, earlier ice break-up has been linked to earlier occurrence of zooplankton grazers (Michel et al. 2015), which has the potential to change dynamics between lower trophic species and endmembers when availability of prey and occurrence of predators become temporally mismatched. In addition to climatic stressors, ice break-up associated with shipping during winter and spring can have an equally profound impact on food-web dynamics and the strength of the sea ice-pelagic-benthic coupling in Arctic ecosystems (Wilson et al. 2004, Yurkowski et al. 2019). Increased shipping in Pond Inlet and Eclipse Sound is still confined to the open-water period (Dawson et al. 2017); however, it is possible that the shipping period will extend over so-called shoulder seasons (late spring and late fall). This raises questions on potential consequences not only for the Inuit community and their ice transit during the ice-covered period, but also for the entire sea ice-dependent ecosystem. Under ice break-up in the fall or winter in the study region, dynamics in sea-ice communities could rather resemble communities of pack ice, characterized by permanently moving ice floes and periodic sea openings (polynyas, leads) during the dark period. Here, the impact might be particularly strong for the sea-ice integrity and thus food web interactions in close proximity to ice-breaking activities along fast-ice edges. Drifting pack-ice floes might experience variability in e.g. temperature, salinity and nutrient supply and exchange rates on a larger scale than landfast ice, which consequently impacts on the nature of ice-algal communities (Abelmann 1992, Gradinger 1999). Incorporation of algae cells in newly formed sea ice might increase with more ice formation and resuspension/mixing present in deeper layers of the water column (Niemi et al. 2011), but, conversely, the constant motion of ice floes could result in a loss of ice algal biomass. Moreover, stronger exposure to solar irradiance, caused by the persistent turn-over of the ice floes as a result of ship movements, can damage algae cells with negative consequences for their food quality to the dependent food web (Leu et al. 2010). Thus, a disruption of the integrity of the sea-ice system in addition to climateinduced changes holds the potential for significant changes in sea ice-associated pelagic and benthic food-web interactions and ecosystem functioning in the study region, and a succession of species with the highest capability for adaption.

\section{CONCLUSIONS}

Chl $a$, FAs, HBIs and SIs were used to trace the trophic signal of sea ice-derived carbon into the benthic system of Eclipse Sound, Canadian Arctic, during May. Considerably higher chl a concentrations in bottom sea ice compared to surface waters indicated that sea ice-derived carbon constituted the main carbon source in this landfast ice environment in spring. All biomarker parameters consistently showed a high 
trophic dependency of the benthic community on sea ice-derived carbon. Based on the distribution of HBIs, we quantified that between 77 and $85 \%$ of the benthic carbon was based on ice algae. Our results reflect the critical role of ice-associated primary production for trophic processes in the study area during the spring ice-covered period. Changes to the sea-ice habitat due to climate warming and shipping throughout the ice-covered period might endanger the important linkage between ice-associated, pelagic and benthic food webs in the Eclipse Sound landfast ice system. We found no evidence to suggest pelagic primary production during the ice-covered period can compensate for the likely future reduced availability of sea ice-derived carbon.

Acknowledgements. This project was funded by Fisheries and Oceans Canada Strategic Program for Ecosystem-Based Research and Advice (SPERA) to C.M. and S.H.F., DFO's Marine Productivity Laboratory funds to C.M. and Natural Sciences and Engineering Research Council of Canada (NSERC) Discovery Grant (C.M. and S.H.F.). D.K. received a NSERC Visiting Fellowship in Canadian Laboratory, supported by SPERA. We thank the Hunters and Trappers Organization in Pond Inlet for kindly supporting our project; Kaven Dionne, Andrew Jaworenko and Brian Komangapik for their excellent support with the field sampling; and we thank Bruno Rosenberg and Anke Reppchen for their help with the laboratory analyses, and Benjamin A. Lange for his help with the map creation. We thank the editor James McClintock and the 2 anonymous reviewers for providing helpful comments and suggestions during the review process.

\section{LITERATURE CITED}

Abelmann A (1992) Diatom assemblages in Arctic sea iceindicator for ice drift pathways. Deep-Sea Res A 39: S525-S538

Ardyna M, Babin M, Gosselin M, Devred E, Rainville L, Tremblay JÉ (2014) Recent Arctic Ocean sea ice loss triggers novel fall phytoplankton blooms. Geophys Res Lett 41:6207-6212

Arrigo KR, Perovich DK, Pickart RS, Brown ZW and others (2012) Massive phytoplankton blooms under Arctic sea ice. Science 336:1408

Assmy P, Fernández-Méndez M, Duarte P, Meyer A, Randelhoff A, Mundy CJ, Olsen L (2017) Leads in Arctic pack ice enable early phytoplankton blooms below snow-covered sea ice. Sci Rep 7:40850

Baffinland Iron Mines Corporation (2016) Mary River project: project update, final report, November 302016. Baffinland Iron Mines Corporation, Oakville

Belt ST, Massé G, Rowland SJ, Poulin M, Michel C, LeBlanc B (2007) A novel chemical fossil of palaeo sea ice: $\mathrm{IP}_{25}$. Org Geochem 38:16-27

Bergé JP, Barnathan G (2005) Fatty acids from lipids of marine organisms: molecular biodiversity, roles as biomarkers, biologically active compounds, and economical aspects. Adv Biochem Eng/Biotechnol 96:49-125
Blais M, Ardyna M, Gosselin M, Dumont D and others (2017) Contrasting interannual changes in phytoplankton productivity and community structure in the coastal Canadian Arctic Ocean. Limnol Oceanogr 62:2480-2497

Bluhm BA, Gradinger RR, Schnack-Schiel SB (2010) Sea ice meio- and macrofauna. In: Thomas D, Diekmann G (eds) Sea ice: an introduction to its physics, biology, chemistry and geology, $2^{\text {nd }}$ edn. Wiley-Blackwell, Oxford, p 357-393

*Boetius A, Albrecht S, Bakker K, Bienhold C and others (2013) Export of algal biomass from the melting Arctic sea ice. Science 339:1430-1432

* Brown TA, Belt ST, Philipe B, Mundy CJ, Massé G, Poulin M, Gosselin M (2011) Temporal and vertical variations of lipid biomarkers during a bottom ice diatom bloom in the Canadian Beaufort Sea: further evidence for the use of the $\mathrm{IP}_{25}$ biomarker as a proxy for spring Arctic sea ice. Polar Biol 34:1857-1868

Brown TA, Belt ST (2012) Identification of the sea ice diatom biomarker $\mathrm{IP}_{25}$ in Arctic benthic macrofauna: direct evidence for a sea ice diatom diet in Arctic heterotrophs. Polar Biol 35:131-137

Brown TA, Belt ST (2017) Biomarker-based H-Print quantifies the composition of mixed sympagic and pelagic algae consumed by Artemia sp. J Exp Mar Biol Ecol 488: 32-37

*Bown TA, Belt ST, Tatarek A, Mundy CJ (2014a) Source identification of the Arctic sea ice proxy $\mathrm{IP}_{25}$. Nat Commun 5:4197

* Brown TA, Yurkowski D, Ferguson S, Alexander C, Belt ST (2014b) H-Print: a new chemical fingerprinting approach for distinguishing primary production sources in Arctic ecosystems. Environ Chem Lett 12:387-392

* Brown TA, Assmy P, Hop H, Wold A, Belt ST (2017) Transfer of ice algae carbon to ice-associated amphipods in the high-Arctic pack ice environment. J Plankton Res 39: 664-674

*Bown TA, Galicia MP, Thiemann GW, Belt ST, Yurkowski DJ, Dyck MG (2018) High contributions of sea ice derived carbon in polar bear (Ursus maritimus) tissue. PLOS ONE 13:e0191631

Budge SM, Springer AM, Iverson SJ, Sheffield G (2007) Fatty acid biomarkers reveal niche separation in an Arctic benthic food web. Mar Ecol Prog Ser 336:305-309

*Budge SM, Wooller M, Springer A, Iverson SJ, McRoy C, Divoky G (2008) Tracing carbon flow in an arctic marine food web using fatty acid-stable isotope analysis. Oecologia 157:117-129

CAFF (2013) Arctic biodiversity assessment. Status and trends in Arctic biodiversity. Conservation of Arctic Flora and Fauna, Akureyri

Campbell K, Mundy CJ, Barber DG, Gosselin M, Giguère N (2014) Remote estimates of ice algae biomass and their response to environmental conditions during spring melt. Arctic 67:375-387

Campbell K, Mundy CJ, Barber DG, Gosselin M (2015) Characterizing the sea ice algae chlorophyll a-snow depth relationship over Arctic spring melt using transmitted irradiance. J Mar Syst 147:76-84

* Caron G, Michel C, Gosselin M (2004) Seasonal contributions of phytoplankton and fecal pellets to the organic carbon sinking flux in the North Water (northern Baffin Bay). Mar Ecol Prog Ser 283:1-13

Cimoli E, Meiners KM, Lund-Hansen LC, Lucieer V (2017) Spatial variability in sea-ice algal biomass: an under-ice 
remote sensing perspective. Adv Polar Sci 28:268-296

Clarke KR, Ainsworth M (1993) A method of linking multivariate community structure to environmental variables. Mar Ecol Prog Ser 92:205-219

Cota GF, Prinsenberg SJ, Bennett EB, Loder JW and others (1987) Nutrient fluxes during extended blooms of Arctic ice algae. J Geophys Res Oceans 92:1951-1962

Walsgaard J, John MS, Kattner G, Müller-Navarra D, Hagen W (2003) Fatty acid trophic markers in the pelagic marine environment. Adv Mar Biol 46:225-340

Dawson J, Copland L, Mussells O, Carter N (2017) Shipping trends in Nunavut 1990-2015: a report prepared for the Nunavut general monitoring program. University of Ottawa. www.espg.ca/wp-content/uploads/2013/04/ NGMP-Shipping-Report_2017-V1.pdf

DeNiro MJ, Epstein S (1978) Influence of diet on the distribution of carbon isotopes in animals. Geochim Cosmochim Acta 42:495-506

Environment and Climate Change Canada (2016) Canadian environmental sustainability indicators: sea ice in Canada (January 31, 2019). http://publications.gc.ca/site/eng/ 9.867937/publication.html

Falk-Petersen S, Sargent J, Henderson J, Hegseth E, Hop H, Okolodkov Y (1998) Lipids and fatty acids in ice algae and phytoplankton from the Marginal Ice Zone in the Barents Sea. Polar Biol 20:41-47

Falk-Petersen S, Haug T, Hop H, Nilssen KT, Wold A (2009) Transfer of lipids from plankton to blubber of harp and hooded seals off East Greenland. Deep Sea Res II 56: 2080-2086

Folch J, Lees M, Sloane Stanley GH (1957) A simple method for the isolation and purification of total lipids from animal tissues. J Biol Chem 226:497-509

Fortier M, Fortier L, Michel C, Legendre L (2002) Climatic and biological forcing of the vertical flux of biogenic particles under seasonal Arctic sea ice. Mar Ecol Prog Ser 225:1-16

Fry B (1988) Food web structure on Georges Bank from stable C, N, and S isotopic compositions. Limnol Oceanogr 33:1182-1190

Fry B, Sherr E (1984) $\delta^{13} \mathrm{C}$ measurements as indicators of carbon flow in marine and freshwater ecosystems. Contrib Mar Sci 27:13-47

Galley RJ, Else BG, Howell SE, Lukovich JV, Barber DG (2012) Landfast sea ice conditions in the Canadian Arctic: 1983-2009. Arctic 65:133-144

* Gosselin M, Legendre L, Therriault JC, Demers S, Rochet M (1986) Physical control of the horizontal patchiness of sea-ice microalgae. Mar Ecol Prog Ser 29:289-298

Gradinger R (1999) Vertical fine structure of the biomass and composition of algal communities in Arctic pack ice. Mar Biol 133:745-754

Graeve M, Kattner G, Hagen W (1994) Diet-induced changes in the fatty acid composition of Arctic herbivorous copepods: experimental evidence of trophic markers. J Exp Mar Biol Ecol 182:97-110

Graeve M, Kattner G, Piepenburg D (1997) Lipids in Arctic benthos: Does the fatty acid and alcohol composition reflect feeding and trophic interactions? Polar Biol 18: 53-61

Haecky P, Jonsson S, Andersson A (1998) Influence of sea ice on the composition of the spring phytoplankton bloom in the northern Baltic Sea. Polar Biol 20:1-8

Harada N (2016) Potential catastrophic reduction of sea ice in the western Arctic Ocean: its impact on biogeochemi- cal cycles and marine ecosystems. Global Planet Change 136:1-17

Harwood J, Russell N (1984) Distribution of lipids. In: Harwood J, Russell N (eds) Lipids in plants and microbes. Springer, New York, NY, p 35-70

Hauser DD, Laidre KL, Stern HL (2018) Vulnerability of Arctic marine mammals to vessel traffic in the increasingly ice-free Northwest Passage and Northern Sea Route. Proc Natl Acad Sci USA 115:7617-7622

*Hays GC, Richardson AJ, Robinson C (2005) Climate change and marine plankton. Trends Ecol Evol 20:337-344

*Hecky R, Hesslein R (1995) Contributions of benthic algae to lake food webs as revealed by stable isotope analysis. J N Am Benthol Soc 14:631-653

* Hobson KA, Ambrose WG Jr, Renaud PE (1995) Sources of primary production, benthic-pelagic coupling, and trophic relationships within the Northeast Water Polynya: insights from $\delta^{13} \mathrm{C}$ and $\delta^{15} \mathrm{~N}$ analysis. Mar Ecol Prog Ser 128:1-10

Fobson KA, Fisk A, Karnovsky N, Holst M, Gagnon JM, Fortier M (2002) A stable isotope $\left(\delta^{13} \mathrm{C}, \delta^{15} \mathrm{~N}\right)$ model for the North Water food web: implications for evaluating trophodynamics and the flow of energy and contaminants. Deep Sea Res II 49:5131-5150

Hollowed AB, Cheng W, Loeng H, Logerwell E, Reist J (2018) Regional assessment of climate change impacts on Arctic marine ecosystems. In: Phillips BF, Pérez-Ramírez $M$ (eds) Climate change impacts on fisheries and aquaculture: a global analysis. Wiley-Blackwell, Hoboken, NJ, p 703-728

Iken K, Bluhm B, Gradinger R (2005) Food web structure in the high Arctic Canada Basin: evidence from $\delta^{13} \mathrm{C}$ and $\delta^{15} \mathrm{~N}$ analysis. Polar Biol 28:238-249

* Iken K, Bluhm B, Dunton K (2010) Benthic food-web structure under differing water mass properties in the southern Chukchi Sea. Deep Sea Res II 57:71-85

Juhl AR, Krembs C (2010) Effects of snow removal and algal photoacclimation on growth and export of ice algae. Polar Biol 33:1057-1065

Juul-Pedersen T, Michel C, Gosselin M, Seuthe L (2008) Seasonal changes in the sinking export of particulate material under first-year sea ice on the Mackenzie Shelf (western Canadian Arctic). Mar Ecol Prog Ser 353:13-25

Kelly JR, Scheibling RE (2012) Fatty acids as dietary tracers in benthic food webs. Mar Ecol Prog Ser 446:1-22

Kenyon KA, Yurkowski DJ, Orr J, Barber D, Ferguson SH (2018) Baffin Bay narwhal (Monodon monoceros) select bathymetry over sea ice during winter. Polar Biol 41: 2053-2063

KKohlbach D, Schaafsma FL, Graeve M, Lebreton B and others (2017) Strong linkage of polar cod (Boreogadus saida) to sea ice algae-produced carbon: evidence from stomach content, fatty acid and stable isotope analyses. Prog Oceanogr 152:62-74

*Kohlbach D, Graeve M, Lange BA, David C, Peeken I, Flores $\mathrm{H}$ (2016) The importance of ice algae produced carbon in the central Arctic Ocean ecosystem: food web relationships revealed by lipid and stable isotope analyses. Limnol Oceanogr 61:2027-2044

Legendre P, Legendre LFJ (2012) Numerical ecology. Developments in environmental modelling, Vol 24. Elsevier, Amsterdam

* Leu E, Falk-Petersen S, Kwa niewski S, Wulff A, Edvardsen K, Hessen DO (2006) Fatty acid dynamics during the spring bloom in a High Arctic fjord: importance of abiotic 
factors versus community changes. Can J Fish Aquat Sci 63:2760-2779

Leu E, Wiktor J, Søreide JE, Berge J, Falk-Petersen S (2010) Increased irradiance reduces food quality of sea ice algae. Mar Ecol Prog Ser 411:49-60

Lovvorn JR, Cooper LW, Brooks ML, De Ruyck CC, Bump JK, Grebmeier JM (2005) Organic matter pathways to zooplankton and benthos under pack ice in late winter and open water in late summer in the north-central Bering Sea. Mar Ecol Prog Ser 291:135-150

Macías-Sánchez MD, Mantell C, Rodriguez MDL, Martínez de la Ossa E, Lubián LM, Montero O (2009) Comparison of supercritical fluid and ultrasound-assisted extraction of carotenoids and chlorophyll a from Dunaliella salina. Talanta 77:948-952

Mahoney A, Eicken H, Gaylord AG, Shapiro L (2007) Alaska landfast sea ice: links with bathymetry and atmospheric circulation. J Geophys Res Oceans 112:C02001

Mäkelä A, Witte U, Archambault P (2017) Benthic macroinfaunal community structure, resource utilisation and trophic relationships in two Canadian Arctic Archipelago polynyas. PLOS ONE 12:e183034

McMahon KW, Ambrose WG Jr, Johnson BJ, Sun MY, Lopez GR, Clough LM, Carrol ML (2006) Benthic community response to ice algae and phytoplankton in Ny Ålesund, Svalbard. Mar Ecol Prog Ser 310:1-14

* Michel C, Legendre L, Therriault JC, Demers S, Vandevelde $\mathrm{T}$ (1993) Springtime coupling between ice algal and phytoplankton assemblages in southeastern Hudson Bay, Canadian Arctic. Polar Biol 13:441-449

Michel C, Legendre L, Ingram R, Gosselin M, Levasseur M (1996) Carbon budget of sea-ice algae in spring: evidence of a significant transfer to zooplankton grazers. J Geophys Res Oceans 101:18345-18360

* Michel C, Nielsen TG, Nozais C, Gosselin M (2002) Significance of sedimentation and grazing by ice micro- and meiofauna for carbon cycling in annual sea ice (northern Baffin Bay). Aquat Microb Ecol 30:57-68

Michel C, Hamilton J, Hansen E, Barber D and others (2015) Arctic Ocean outflow shelves in the changing Arctic: a review and perspectives. Prog Oceanogr 139:66-88

Minagawa M, Wada E (1984) Stepwise enrichment of ${ }^{15} \mathrm{~N}$ along food chains: further evidence and the relation between $\delta^{15} \mathrm{~N}$ and animal age. Geochim Cosmochim Acta 48:1135-1140

Müller-Navarra DC, Brett MT, Liston AM, Goldman CR (2000) A highly unsaturated fatty acid predicts carbon transfer between primary producers and consumers. Nature 403:74-77

* Mundy CJ, Barber D, Michel C (2005) Variability of snow and ice thermal, physical and optical properties pertinent to sea ice algae biomass during spring. J Mar Syst 58:107-120

Mundy CJ, Ehn J, Barber D, Michel C (2007) Influence of snow cover and algae on the spectral dependence of transmitted irradiance through Arctic landfast first year sea ice. J Geophys Res Oceans 112:C03007

$\mathrm{Ng}$ AK, Andrews J, Babb D, Lin Y, Becker A (2018) Implications of climate change for shipping: opening the Arctic seas. Wiley Interdiscip Rev Clim Change 9:e507

Niemi A, Michel C, Hille K, Poulin M (2011) Protist assemblages in winter sea ice: setting the stage for the spring ice algal bloom. Polar Biol 34:1803-1817

Parrish CC, Thompson RJ, Deibel D (2005) Lipid classes and fatty acids in plankton and settling matter during the spring bloom in a cold ocean coastal environment. Mar Ecol Prog Ser 286:57-68

Parsons T, Maita Y, Lalli C (1984) A manual of chemical and biological methods for seawater analysis. Pergamon Press, New York, NY

Paul D, Skrzypek G, Fórizs I (2007) Normalization of measured stable isotopic compositions to isotope reference scales-a review. Rapid Commun Mass Spectrom 21: 3006-3014

* Piepenburg D (2005) Recent research on Arctic benthos: common notions need to be revised. Polar Biol 28: 733-755

* Pizzolato L, Howell SE, Derksen C, Dawson J, Copland L (2014) Changing sea ice conditions and marine transportation activity in Canadian Arctic waters between 1990 and 2012. Clim Change 123:161-173

* Pizzolato L, Howell SE, Dawson J, Laliberté F, Copland L (2016) The influence of declining sea ice on shipping activity in the Canadian Arctic. Geophys Res Lett 43: 12146-12154

*Post DM (2002) Using stable isotopes to estimate trophic position: models, methods, and assumptions. Ecology 83: 703-718

R Core Team (2017) R: a language and environment for statistical computing. R Foundation for Statistical Computing, Vienna

Renaud PE, Riedel A, Michel C, Morata N, Gosselin M, JuulPedersen T, Chiuchiolo A (2007) Seasonal variation in benthic community oxygen demand: A response to an ice algal bloom in the Beaufort Sea, Canadian Arctic? J Mar Syst 67:1-12

Richard P, Weaver P, Dueck L, Barber D (1994) Distribution and numbers of Canadian High Arctic narwhals (Monodon monoceros) in August 1984. Medd Gronl Biosci 39: 41-50

Riedel A, Michel C, Gosselin M (2006) Seasonal study of sea-ice exopolymeric substances on the Mackenzie shelf: implications for transport of sea-ice bacteria and algae. Aquat Microb Ecol 45:195-206

* Roy V, Iken K, Gosselin M, Tremblay JÉ, Bélanger S, Archambault P (2015) Benthic faunal assimilation pathways and depth-related changes in food-web structure across the Canadian Arctic. Deep-Sea Res I 102:55-71

Sargent J, Whittle K (1981) Lipids and hydrocarbons in the marine food web. In: Longhurst AR (ed) Analysis of marine ecosystems. Academic Press, New York, NY, p 491-533

* Sejr MK, Nielsen TG, Rysgaard S, Risgaard-Petersen N, Sturluson M, Blicher ME (2007) Fate of pelagic organic carbon and importance of pelagic-benthic coupling in a shallow cove in Disko Bay, West Greenland. Mar Ecol Prog Ser 341:75-88

Shokr M, Sinha N (2015) Sea ice: physics and remote sensing. American Geophysical Union, Washington, DC

* Sinha N, Zhan C (1996) Primary dendrite spacing in landfast polar sea ice. J Mater Sci Lett 15:2118-2121

* Smith TG (1980) Polar bear predation of ringed and bearded seals in the land-fast sea ice habitat. Can J Zool 58: 2201-2209

* Smith LC, Stephenson SR (2013) New trans-Arctic shipping routes navigable by midcentury. Proc Natl Acad Sci USA 110:E1191-E1195

Smith REH, Anning J, Clement P, Cota G (1988) Abundance and production of ice algae in Resolute Passage, Canadian Arctic. Mar Ecol Prog Ser 48:251-263 
Søreide JE, Carroll ML, Hop H, Ambrose WG Jr, Hegseth EN, Falk-Petersen S (2013) Sympagic-pelagic-benthic coupling in Arctic and Atlantic waters around Svalbard revealed by stable isotopic and fatty acid tracers. Mar Biol Res 9:831-850

Stroeve J, Notz D (2018) Changing state of Arctic sea ice across all seasons. Environ Res Lett 13:103001

Tamelander T, Renaud PE, Hop H, Carroll ML, Ambrose WG Jr, Hobson KA (2006) Trophic relationships and pelagic-benthic coupling during summer in the Barents Sea Marginal Ice Zone, revealed by stable carbon and nitrogen isotope measurements. Mar Ecol Prog Ser 310: 33-46

* Tamelander T, Kivimäe C, Bellerby RG, Renaud PE, Kristiansen S (2009) Base-line variations in stable isotope values in an Arctic marine ecosystem: effects of carbon and nitrogen uptake by phytoplankton. Hydrobiologia 630:63-73

Volkman JK, Barrett SM, Dunstan GA (1994) $\mathrm{C}_{25}$ and $\mathrm{C}_{30}$ highly branched isoprenoid alkenes in laboratory cultures of two marine diatoms. Org Geochem 21:407-414

Wang SW, Budge SM, Iken K, Gradinger RR, Springer AM, Wooller MJ (2015) Importance of sympagic production to Bering Sea zooplankton as revealed from fatty acid-carbon stable isotope analyses. Mar Ecol Prog Ser 518:31-50
Warner G (1982) Food and feeding mechanisms: Ophiuroidea. In: Jangoux M, Lawrence JM (eds) Echinoderm nutrition. AA Balkema, Rotterdam, p 161-181

*Wassmann P (2015) Overarching perspectives of contemporary and future ecosystems in the Arctic Ocean. Prog Oceanogr 139:1-12

*Wassmann P, Reigstad M (2011) Future Arctic Ocean seasonal ice zones and implications for pelagic-benthic coupling. Oceanography (Wash DC) 24:220-231

*Wassmann P, Duarte CM, Agusti S, Sejr MK (2011) Footprints of climate change in the Arctic marine ecosystem. Glob Change Biol 17:1235-1249

Welch HE, Bergmann MA (1989) Seasonal development of ice algae and its prediction from environmental factors near Resolute, NWT, Canada. Can J Fish Aquat Sci 46: 1793-1804

Wilson KJ, Falkingham J, Melling H, De Abreu R (2004) Shipping in the Canadian Arctic: other possible climate change scenarios. In: IGARSS'04: IEEE International Geoscience and Remote Sensing Symposium, Vol 3, 20-24 September 2004, Anchorage, AK. IEEE International, New York, NY, p 1853-1856

Yurkowski DJ, Young BG, Dunn B, Ferguson SH (2019) Spring distribution of ringed seals (Pusa hispida) in Eclipse Sound and Milne Inlet, Nunavut: implications for potential ice-breaking activities. Arctic Sci 5:54-61

\section{Appendix}

Table A1. Chlorophyll a concentrations (mean $\pm 1 \mathrm{SD}$ ) in the bottom ice, surface water and sediment samples collected during May 2018 in

Eclipse Sound. (-) Not determined

\begin{tabular}{|ccccc|}
\hline \multirow{2}{*}{ Station } & \multicolumn{3}{c}{ Bottom ice $\begin{array}{c}\text { Surface waters } \\
\left(\mu \mathrm{g} \mathrm{l}^{-1}\right)\end{array}$} & $\begin{array}{c}\text { Sediments } \\
\left(\mu \mathrm{g} \mathrm{g}^{-1}\right)\end{array}$ \\
\cline { 2 - 5 } & $\left(\mu \mathrm{g} \mathrm{I}^{-1}\right)$ & $7.9 \pm 0.1$ & $0.1 \pm 0.1$ & - \\
\hline 1 & $185.8 \pm 0.6$ & 15.9 & $1.6 \pm 0.3$ & - \\
2 & $295.4 \pm 0.6$ & $13.9 \pm 0.1$ & $0.3 \pm 0.1$ & - \\
3 & 327.2 & 15.4 & $0.7 \pm 0.1$ & - \\
4 & $308.4 \pm 62.0$ & $15.5 \pm 3.1$ & - \\
5 & $566.5 \pm 120.7$ & $26.4 \pm 5.6$ & $0.6 \pm 0.2$ & - \\
6 & $532.7 \pm 45.4$ & $24.3 \pm 2.1$ & $2.1 \pm 0.1$ & - \\
7 & $615.5 \pm 4.3$ & $26.3 \pm 0.2$ & $0.8 \pm 0.1$ & - \\
8 & $387.7 \pm 45.6$ & $18.3 \pm 2.2$ & $1.7 \pm 0.2$ & - \\
9 & $594.0 \pm 26.2$ & $28.0 \pm 1.2$ & $0.6 \pm 0.1$ & - \\
10 & $568.9 \pm 42.8$ & $21.5 \pm 1.6$ & $0.7 \pm 0.1$ & - \\
11 & - & - & $1.8 \pm 0.2$ & $0.4 \pm 0.2$ \\
12 & - & - & $0.6 \pm 0.1$ & $0.4 \pm 0.1$ \\
13 & - & - & $0.5 \pm 0.1$ & 0.1 \\
14 & - & - & $3.2 \pm 0.3$ & 0.5 \\
& & & & \\
\hline
\end{tabular}


Table A2. Relative contributions of the different highly branched isoprenoids and estimated relative contributions of sea ice-derived carbon (mean $\pm 1 \mathrm{SD}$ ) in the bottom-ice samples collected during May 2018 in Eclipse Sound. Proportions of III are equivalent to the H-Print. See Section 2.4 for details on estimates of sea ice-derived carbon contributions

\begin{tabular}{|ccccc|}
\hline Station & $\mathrm{IP}_{25}(\%)$ & $\mathrm{II}(\%)$ & $\begin{array}{c}\mathrm{III}(=\mathrm{H}-\mathrm{Prin}) \\
(\%)\end{array}$ & $\begin{array}{c}\text { Sea ice-derived } \\
\text { carbon }(\%)\end{array}$ \\
\hline 1 & $29.1 \pm 2.5$ & $66.8 \pm 3.1$ & $4.1 \pm 0.6$ & $96.9 \pm 0.6$ \\
2 & $38.3 \pm 5.2$ & $42.6 \pm 4.6$ & $19.1 \pm 0.6$ & $81.6 \pm 0.6$ \\
3 & $34.8 \pm 0.8$ & $53.3 \pm 0.2$ & $11.8 \pm 0.6$ & $89.0 \pm 0.6$ \\
4 & $42.9 \pm 1.3$ & $43.1 \pm 1.9$ & $14.0 \pm 3.3$ & $86.8 \pm 3.3$ \\
5 & $36.6 \pm 2.2$ & $54.9 \pm 3.7$ & $8.5 \pm 1.5$ & $92.4 \pm 1.5$ \\
6 & 37.5 & 54.1 & 8.4 & 92.5 \\
7 & $38.0 \pm 0.1$ & $49.2 \pm 2.2$ & $12.8 \pm 2.2$ & $88.0 \pm 2.2$ \\
8 & $32.4 \pm 0.4$ & $53.5 \pm 0.2$ & $14.1 \pm 0.6$ & $86.7 \pm 0.6$ \\
9 & $37.4 \pm 1.0$ & $42.7 \pm 0.7$ & $19.9 \pm 0.3$ & $80.8 \pm 0.3$ \\
10 & $32.3 \pm 2.5$ & $37.1 \pm 4.9$ & $30.5 \pm 2.5$ & $69.9 \pm 2.5$ \\
\hline
\end{tabular}

Editorial responsibility: James McClintock, Birmingham, Alabama, USA
Submitted: March 12, 2019; Accepted: July 11, 2019 Proofs received from author(s): September 22, 2019 